\title{
Pendampingan Ekonomi Pesantren Melalui Sentralisasi Transaksi Cost makan Santri di Pondok Pesantren Nurul Jadid Paiton
}

\author{
Ainol Yaqin*, Maknunatun Navisah Arifin, Zaimatul Umami, Siti Ruqoyyah, \\ Dwi Anggraini Novitasari, Ika Sulistyawati
}

Universitas Nurul Jadid, Paiton, Probolinggo, Indonesia

\begin{abstract}
In one of the efforts to increase the economic progress of the pesantren and also to eat for the students, especially at the Nurul Jadid Boarding School, Probolinggo, it is very necessary to have a centralized program for paying the cost of paying for the cost of the students' meals so that each student's meal is regelated and even becomas a way of saving the cost of living for the students. For decades, the Nurul Jadid Islamic Boarding School has not been able and succeeded ini centralizing the cost of food for students and processed food products for students at one door. The centralization of the santri staple food business is believed by the pesantren. The fear of pesantren in managing this business is quite an obstacle, but by providing location, technology and human resources, pessntren is expected to be able to maintain and preserve Costmara's business. Our service uses a Consultation approach, where wa several individuals at the same time assist, guide and direct policy makers, employees and servants at Nurul Jadid Cost of Eating student to make this businenss lively and comfartable, especially able to nourish the economy of the Pesantren and serve the needs of the santri so that the pesantren achieves the peak of independence and economic sovereignty. Centralization of the cost of meals for studentswas initiated by Pesantren bereau and ini teh end it was acquired by the business bereua, Centralized peyments at the santri supplies simpab office and food management in public kitchens with a sufficient number of employess, centralization of santri food and payments were able to mave the pesantren economy for more beneficial interests including religious agends, education, health, equipment and others within the Nuru Jadid Islamci Boarding School. Economics is the foundation of every pesantren agenda. So Cost Mara contributes a lot the economic pace of Islamic Boarding Schools. Santru obtain sufficient benefits, including low prices, healthy composition and savings for santri and the ecomic flow santri guardiens.
\end{abstract}

Keywords: Cost Of Eating, Santri, Economic Pesantren, Centralization Transction.

\section{Pendahuluan}

Cita-cita pesantren yang sangat besar yaitu ingin mencetak santri yang dapat menguasai bidang agama, kemajuan teknologi yang sangat pesat, kesahatan, industri dan ekonomi yang pada era modern ini menjadi garapan semua pesantren di penjuru Nusantara. Beberapa upaya dan cara sudah dilakukan oleh pesantren untuk mencetak kader yang diinginkan, salah satu upaya yang telah dicoba dan berjalan sampai sekarang yaitu dengan munculnya Costmakan santri sehingga dalam hal makan santri sudah tak lagi mencari makan ke warung-warung yang ada dikawasan pondok pesantren. Pesantren dalam beberapa hal akan mengambil alih, mengatur dan mengintegrasikan arus ekonomi menjadi satu pintu, dewasa ini pesantren telah berupaya untuk mengambil kesempatan momentum dalam menggerakkan ekonomi pesantren. Dalam istilah lain pesantren telah menjalani proses perubahan sosial (social change), bukan lagi hanya tertumpu dalam aspek pendalaman ilmu agama saja (tafaquh $f \hat{E}$ al-din ) tetapi juga aspek ekonomi. Antara

\footnotetext{
* Corresponding author:

E-mail address: ainolyaqin1991@gmail.com
} 
langkah yang diambil pesantren pada beberapa dekade ini yaitu dengan mendirikan koperasi yang beroperasi di dalam pondok pesantren atau biasa disebut dengan istilah (Kopontren). (Syamsuri, 2019)

Tujuan pondok pesantren adalah membentuk manusia yang memiliki kesadaran yang tinggi bahwa ajaran Islam bersifat konprehensif. (Misjaya, 2019) Islam memposisikan manusia sebagai poros penggerak proses pembangunan dalam kehidupan. (Fitria Nurul Azizah, 2020) Ekonomi pesantren mempunyai peran penting dalam memenuhi hajat manusia jamak, guru, pengurus, keluarga, abdi dalem, pengabdi, santri dan masyarakat sekitar pesanstren terbatu dengan pemberdayaan ekonomi pesantren, terlebih jika ekonomi tersebut hidup menekan akan murahnya biaya kehidupan santri yang berdampak akan ringannya beban wakli santri. Sebagai tujuan, maka pemberdayaan menunjuk pada keadaan atau hasil yang ingin dicapai, dan konsep mengenai tujuan pemberdayaan ini seringkali digunakan sebagai indikator keberhasilan pemberdayaan sebagai sebuah proses. (Utama, 2020) Baru-baru ini disadari atau tidak bahwa keberadaan pondok pesantren juga mempengaruhi pergerakan sosial ekonomi. (Akhmad Haryono, 2021) Kegiatan ekonomi dilakukan manusia untuk memenuhi kebutuhanny. (Zainuddin, 2021) Secara umum pertumbuhan ekonomi dapat diartikan perkembangan kegiatan dalam perekonomian yang menyebabkan barang dan jasa yang diproduksi dalam masyarakat bertambah dan kemakmuran masyarakat meningkat. (Yasin, 2020)

Salah satu fakor yang dapat meningkatkan pendapatan individu/kelompok ialah kewirausahaan. Kewirausahaan juga akan melahirkan kemandirian ekonomi masyarakat. (Sirajjuddin, 2021) Materi dan aplikasi kewirausahaan sangat urgen bagi santri, masyarakat sekitar dan pengabdi. Pola pemberdayaan bagi masyarakat khususnya bagi remaja merupakan mekanisme yang memberikan peluang untuk memperkaya ilmu pengetahuan dan pengalaman melalui berbagai kegiatan produktif yang dapat mendukung perekonomian. (Idris, 2020) Peran pondok pesantren dalam pembangunan terhadap masyarakatnya kian memperkokoh eksistensi pondok pesantren. (M. Ni'am, 2021) Faktor keterbatasan akses ekonomi pesantren akan menambah jumlah kemiskinan dan penganguran di masa depan, Keterbatasan ekonomi menyebabkan pendidikan generasi muda tidak memperoleh prioritas. (Erick F, 2020)

Pesantren Nurul Jadid Paiton Probolinggo terus mengembangkan dan memajukan ekonomi pesantren sebagai garda terdepan dan roda berjalannya semua kegiatan pesantren meliputi pendidikan, kesehatan, keagamaan, kesejahteraan dan laiinya, keinginan pesantren dalam mengembangkan ekonomi merupakan kepedulian masyarakat pesantren terhadap arus keuangan pesantren d atas $20 \mathrm{M}$ setiap tahunnya. Pondok Pesantren Nurul Jadid dengan sekian jumlah santri yang tidak sedikit berupaya dan bertekad untuk mengintegrasikan kebutuhan makan santri, pendanaan dan pembayaran pada satu pintu. Hal, ini menjadi dasar dimana kami mempunyai inisiasi mengbdikan diri kami bersama mahasiswi untuk mendapmpingi pengelolaan dana santri, komposisi vitamin makanan, pemasaran prodak makanan, pendampingan terhadap para pengabdi serta arus keuangan santri dimana individu santri membayar tiga ratus ribu setiap bulannya dengan jumlah santri ribuan.

Bertitik tolak dari uraian yang dikemukakan diatas, maka kami tertarik untuk mengadakan pengabdian sebagai bagain dari dunia akademis yang berjudul "Pendampingan ekonomi pesantren melalui sentralisasi transaksi Costmakan santri di pondok Pesantren Nurul Jadid" yang bertujuan :

A. Untuk mengananalisis proses sentralisasi Cost makan santri Pondok Pesantren Nurul Jadid

B. Untuk mrnganalisis proses transaksi cost makan santri Pondok Pesantren Nurul Jadid

C. Untuk menganalisis dampak adanya sentralisasi transaksi Cost makan santri terhadap ekonmi pesantren

D. Untuk meningkatkan pelayanan transaksi Cost makan terhadap santri di Pondok Pesantren Nurul Jadid

\section{Metode}

Metode pengabdian ini adalah menggunakan pendekatan Kualitatif dengan jenis pengabdian ini adalah pengabdian lapangan, dimana kami mendapampingi, menemani dan menyertai semua pelaku dan pegawai Dapur Umum Costmakan Santri Pondok Pesantren Nurul Jadid Paiton Probolinggo. Metoda yang digunakan adalah Observasi, Wawancara dan dokumentasi, dimana semua intsrumen dari pengabdian ini menjadi bekal dan dasar penyimpulkan hasil dari pengabdian mulia ini . 


\subsection{Lokasi Penelitian}

Kegiatan ini dilaksanakan pada Dapur Umum Costmakan Santri di lingkungan Pondok Pesantren Nurul Jadid Paiton Probolinggo, dapur umu Kosmakan santri dekat dengan pintu gerbang masuk Pondok Pesantren.

\subsection{Waktu Penelitian}

Pengabdian ini dilaksanakan pada tanggal 1 Maret - 30 Juli pada Cost makan Santri Pondok Pesantren Nurul Jadid Paiton Probolinggo

\subsection{Populasi dan Sampel Penelitian}

\section{(a) Populasi Penelitian}

Populasi dalam penelitian ini adalah 50 Santri di Pondok Pesantren Nurul Jadid Paiton Probolinggo dan pegawai Cost Makan yang telah dipilih oleh peneliti untuk mewakili disetiap asrama masing- masing untuk memperoleh data yang valid. dan pemilik kebijakan serta pegawai usaha KOSMARA Pondok Pesantren Nurul Jadid.

\section{(b) Sampel Penelitian}

Sampel yang digunakan dalam penelitian ini berjumlah 50 Santri aktif dan Pagawai Usaha Cost Makan Pesantren Nurul Jadid Paiton Probolinggo dengan menggunakan Teknik Purposive sampling yang diambil dengan menggunakan Teknik Purposive sampling yang berarti Teknik pengambilan sampel secara menghasilkan sampel yang secara logis yang dapat dianggap mewakil populasi.

\section{Hasil dan Pembahasan}

\subsection{Sejarah (Tarikh)}

Didalam sejarah adanya Cost makan santri Nurul Jadid berawal dari cita cita dari Kepala Biro Pesantren Nurul Jadid yang pada waktu itu Gus Muhammad Imdad Rabbani sebagaai ketua Biro Kepesatrenan, beliau melihat kebanyakan santri pada jam sekolah masih mencari sarapan pagi diwarung-warung, namun warung yang ada di kawasan tidak sebanding jumlah dengan para santri yang ada sehingga dampaknya akan berpengaruh kepada seringnya keterlambatan masuk sekolah, sehingga pada tahun 2018 Biro Kepesantrenan mengadakan rapat terkait problem ini, sehingga diputuskanlah adanya Cost makan santri dengan harapan tidak ada keterlambatan para santri untuk masuk sekolah lebuh-lebih dalam mengikuti kegiatan pesantren.

Seiring berjalannya waktu untuk meningkatkan kuwalitas dari adanya kosmakan santri serta pelayanan terhadap santri, maka pada bulan Juli 2020 Biro Kepesantrenan mengadakan rapat dengan hasil pucanknya bahwa Cost makan santri dialihkan kepada Biro Usaha dengan nama SBS ( Simpana Bekal Santri ) menaungi Cost makan dan E-Bekal santri yang memuat keprluan pembayaran tagihan santri baik dalam hal biaya, tagihan-tagihan biaya pesantren dan uang jajan santri, hasil rapat tersebut yaitu sentralisasi warung makan santri menjadi satu dapur yang bertempatan di koperasi Daltim pintu masuk lingkungan pesantren. Dari keputusan dari rapat tersebut menghilangkan permasalahan yang ada, antara lain terpenuhnya jumlah Cost makan dengan jumlah santri di Pondok pesantren Nurul Jadid dan pembayaran terhapat Cost makan santri meningkat setalah adanya Sentralisi pembayaran, Untuk lebih jelasnya perlu diadakan pendekatan ilmiah untuk mengungkap jawaban dari permasalahan yang berhubungan dengan Cosmara, khususnya yang berhubungan dengan sentralisasi transaksi.. 


\subsection{Potensi Ekonomi}

Dalam pembelanjaan setiap harinya dilakukan oleh tim SBS untuk memenuhi kebutuhan dapur dengan mengukur jumlah santri yang ada di data reservasi makan pedatren yang diimput langsung oleh wali asuh masing-masing kamar disetiap wilayah. Setelah melakukan pembelanjaan kebutuhan dapur, proses selanjutnya diserahkan kepada pihak dapur untuk diolah dengan berdasarkan kebutuhan jumlah nasi setiap harinya, setelah proses pengolahan selesai kemudian langkah yang selanjutkan diserahkan kembali kepada pihak SBS yang nantinya pihak SBS yang akan menyerahkan langsung kepada penjab Cosmara masing- masing wilayah, setelah itu baru penjab Cosmara dari masing masing wilayah yang akan memberikan kepada masing-masing santri. Menu menu tersebut bisa berubah pada suatu saat sesuai rapat evaluasi bulanan dari pihak pesantren dengan berdasarkan langkanya bahan pangan yang tersedia dipasar.

Potensi ekonomi dari usaha Cost Makan santri sangat menjanjikan dan mampu mendorong ekonomi pondok pesantren Nurul Jadid, pertumbuhan dan sinergitas ekonomoi pesantren melalui santraliasai keuangan makan santri dan penyedian makan santri pada satu dapur mampu menghidupkan ekonomi pesantren. Jumlah santri 6.500 dengan kewajiban pembayaran 300.000 setiap bulannya bukanlah angka yang sedikit, hal itu bisa diukur bagaimana kesibukan setiap harinya bagi penyedia makanan santri, pengelola keuangan dan petugas Dapur Umum. Usaha ini tidak hanya individu pada pesantren, melainkan juga menambah penghasilan masyarakat pesantren dan pengabdi di lingkungan Nurul Jadid, terlebih menciptakan kesederhanaan sirkulasi keungan santri, sebab makanan pokok mereka telah terukur dan ternominalkan. Peredarana keuangan di Dapur Umum tentunya dalam angka jutaan sedangkan peredaran teransaksi santri dengan pesantren berada pada angka miliaran rupiah, adalah angka besar untuk menciptkan kemandirian ekonomi dan mengurangi angka kemiskinan, jumlah pengangguran dan ketimpangan ekonomi.

Tabel 1. Nominal Pendapatan Kotor Cost Makan Santri Nurul Jadid

\begin{tabular}{cccc}
\hline NO & Jumlah Santri & Harga Nasi+Lauk & Jumlah \\
\hline 1 & 6.500 & Rp300.000 $\times 1$ bulan $\times 6.500$ & Rp1.950.000.000 \\
\hline
\end{tabular}

Jumlah pembayaran santri setiap bulannya adalah dua miliar kurang lima puluh juta rupiah atau satu miliar sembilan ratus lima puluh juta rupiah, pembayaran dengan jumlah di atas dalam kurun satu bulan, tentunya santri yang mondok minimal tiga tahun bahkan hingga lebih delapan tahun. Jika pemabyan Cost Makan dengan jumlah diatas dalam kurun satu tahun menyentuh nominal $22 \mathrm{M}$ (Dua puluh dua Miliar rupiah). Sehingga pesantren tertarik dan ingin mengelolah kesempatan emas ini untuk kemaslahatan jamak baik bagi pesantren, mayarakat, santri dan lingkungan yang bersentuhan dengan pesantren. Terlebih bagaimana pesantren Nurul Jadid lebih menyentuh pada penyedian bahan pokok dan baku, sehingga line ekonomi bisa dikembangkan. Jumlah laba kotor diatas $22 \mathrm{M}$ menjadi lahan basah bagi perkembangan ekonomi pesantren Nurul Jadid untuk mengambangkan laba bersih dari Cost Makan ribuan santri pada bidang Pendidikan, Keagamaan, Kesehatan dan lainnya.

Tabel 2. Menu Makan Santri

\begin{tabular}{llll}
\hline & & & \multicolumn{2}{c}{ Menu Makan Santri } \\
\hline \multirow{2}{*}{1} & \multirow{2}{*}{ Sabtu } & Pagi & Tahu gore, sambel, tempe dikuah kuning (dibungkus)* \\
\cline { 3 - 4 } & & Sore & Dadar jagung, sambel, tempe krispy (ukuran diperbesar), dan kuah sup (dibungkus)* \\
\cline { 3 - 4 } 2 & \multirow{2}{*}{ Ahad } & Pagi & Tahu gore, sambel, tempe dikuah merah (dibungkus)* \\
\cline { 3 - 4 } & \multirow{2}{*}{3} & Sore & tempe kecil-kecil masak kecap, sambel, osing-osing teri \\
\cline { 3 - 4 } & \multirow{2}{*}{4} & pagi & Telur, sambel pecel (dibungkus)* \\
\cline { 3 - 4 } & \multirow{2}{*}{ Selasa } & sore & Menu spesial** \\
\cline { 2 - 4 } & & sogi & sambel, tempe dan tahu keci-kecil dilodeh tidak pedas (dibungkus)* \\
\hline 5 & Rabu & pagi & tahu dan tempe kecap, samel, kuah sop (dibungkus)* \\
\hline
\end{tabular}




\begin{tabular}{llll}
\hline & & & \multicolumn{2}{c}{ Menu Makan Santri } \\
\hline \multirow{2}{*}{6} & \multirow{2}{*}{ Kamis } & sore & Dadar jagung, sambel, tempe krispy, sambel, dan kuah sup (dibungkus)* \\
\cline { 3 - 4 } & \multirow{2}{*}{7} & pagi & Telur, sambel pecel (dibungkus)* \\
\hline \multirow{2}{*}{ Jumat } & sore & Menu spesial** \\
\cline { 3 - 3 } & & Pagi & Nasi goreng atau nasi kuning, sambel dan telurgulung \\
\cline { 3 - 3 } & & Sore & tempe kecil-kecil masak kecap, sambel, osing-osing teri \\
\hline
\end{tabular}
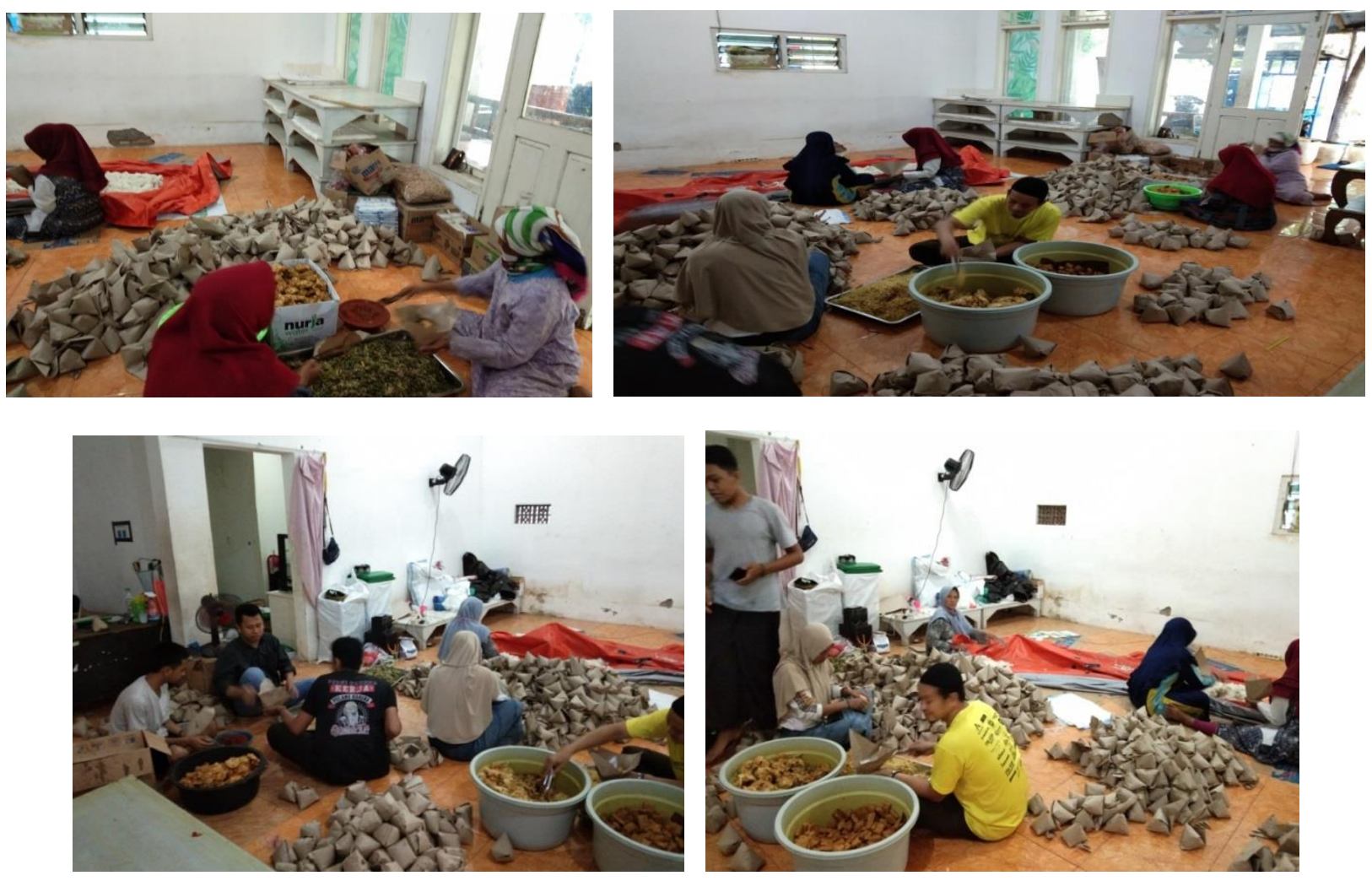

Fig. 1. Suasana Penyediaan Makan Santri

\section{Kesimpulan}

Berdasarkan hasil dan pembahasan dapat disimpulkan sebagai berikut:

- Sentralisasi Cost Makan santri digagas oleh Biro Kepesantrenan kemudian diakuisisi oleh Biro Usaha

- Transkasi Pembayara Cost Makan santri satu pintu ke bagian SBS melalui Card E-Bekal setiap santri

- Ekonomi Pesantren terbantu oleh usaha Cost Makan santri satu pintu, sebab peredaran bisnis ini diatas $22 \mathrm{M}$ setiap tahunnya.

- Santri terbantu adanya Cost Makan, sebab menu dan komposisi sesuai dengan kesehatan dan kebutuhan santri.

\section{Acknowledgements}

Kami berterima kasih kepada segenap mahasiswi yang telah banyak menyertai kami dalam pengabdian mulia ini, kepada pemangku kebijakan Cost Mara, Biro Usaha, Pegawai Cost Mara serta bagi mereka yang ikut serta dalam 
pengabdian ini hingga selesai, semoga menjadi amal kebaikan bagi kita semua serta bertambahnya karya ilmiah demi kemajuan pendidikan di Indonesia.

\section{References}

Akhmad Haryono, I. B. (2021). Pendampingan Kewirausahaan Rias Pengantin Sebagai Peningkatan Kemandirian. $A B D I$, Vol. 7 No. 1.

Erick F, H. G. (2020). Pesantren Mandiri Pangan, Program Pelatihan Optimasi Pemanfaatan Lahan Kritis Berbasis Pertanian Terpadu di PP. Al-Hikmah Gunung Kidul . JMM (Jurnal Masyarakat Mandiri), Vol. 4, No. 5, November, Hal. 797-805.

Fitria Nurul Azizah, M. A. (2020). Pembangunana Masyarakat Berbasisi Pembangunan Ekonomi Pesantren . Jurnal Ilmiah Ekonomi Islam (JIEI), 6(03), 2020, 645-653.

Idris, D. Z. (2020). Pemberdayaan Dan Pengembangan Ekonomi Masyarakat Melalui Pemanfaatan Limbah Organik Berbasisi Lingkungan . Journal of Community Service, Vol. 2 No. 2.

M. Ni'am, I. R. (2021). Kontribusi Pondok Pesantren Dalam Mengembangkan Human Capital. Jurnal Pembangunan Manusia, Vol. 2 No. 1 hal-2-28 .

Misjaya, D. S. (2019). Konsep Pendidikan Kemandirian Ekonomi Di PP.. Mukmin Sidoarjo Jawa Timur. Edukasi Islami, Vo; : 8 No. 1.

Sirajjuddin, J. (2021). Pengaruh Pendidikan Kewirausahaan Terhadap Minat Berwirausaha Siswa Di PP. Al-Manar Cibeutiung Udin Kecamatan Ciseng Bogor. Journal of Economic, Management, Accounting and Technology (JEMATech), Vol. 4 No. 1.

Syamsuri. (2019). Strategi pengembangan ekonomi berdikari di pesantren Gontor berbasis pengelolaan Kepontren. AL-INTAJ, Vol. 6 No. 1.

Utama, R. E. (2020). Strategi Pembiayaan Pesantren Melalui Pemberdayaan. Jurnal TAHDZIBI, Vol. 5 No. 2.

Yasin, M. (2020). Analisis Pendapatan Asli Daerah dan Belanja Pembangunan Terhadap Pertumbuhan Ekonomi Kota Di Jawa Timur. COSTING:Journal of Economic, Business and Accounting, Vol. 3 No. 2 Juni.

Zainuddin, B. M. (2021). Peningkatan Ekonomi Pesantren, Melalui Generasi Anti Riba. Jurnal Pengabdian Masyarakat Indonesia (JPMI), Vol 1 No. 4 hal 127-134. 